\title{
THE CREATIVE CINEMATOGRAPHIC PROCESS AT THE SERVICE OF NATIONAL IDENTITY: PEDRO ALMODÓVAR AND THE PROMOTION OF SPANISH STEREOTYPES
}

\author{
Marta SAAVEDRA LLAMAS (1), Nicolás GRIJALBA DE LA CALLE (10* \\ Nebrija University, School of Communication and Arts, Department of \\ Communication 28015, Madrid, Spain
}

Received 10 February 2019; accepted 6 May 2020

\begin{abstract}
Cultural expression and creativity contribute to shape national identity; movie experience reflects society. The way in which Pedro Almodóvar's films facilitates a greater understanding of Spanish culture is the main thesis in this research. This study follows a double methodology: a descriptive documentary phase and an analysis of the filmmaker's work. The latter includes two substages: a qualitative analysis based on a pattern dealing with different variables related to stereotype perception of Spain abroad; and a quantitative one, which highlights further procedures to approach the national culture. The insight provided by this research proves that Almodóvar actually spreads Spanish identity through his creative universe and empowers its stereotypes, yet by making them more modern: he points out the role of family, but he goes against the traditional model; he turns Madrid, Spain symbolic sight in the international standard about Spanish identity, into the kernel of his work; and he introduces some elements of Spanish popular culture like folklore, gastronomy, bullfighting or rural Spain.
\end{abstract}

Keywords: costumbrismo, creativity, family, national identity, Madrid, Pedro Almodóvar, Spanish stereotypes.

\section{Introduction}

All cultural expressions are necessary discourses for the construction of national identities. As it happened with the pictorial practice and later with photography, cinema, the magical depiction of modern life, has reflected on memory and recognition since its origins.

Thus, the cinematographic experience has become a decisive mirror of different societies. While the camera captures images of symbolic content, film discourses become solid showcases for the promotion of multiple identities. Cinema, in the words of Barthes (1986), is a perfect trap, an artifact capable of combining the real with the imaginary.

The national question, it could not be otherwise, was a direct concern for the Spanish industry. This research proposes the study of national construction in Spanish cinema and,

*Corresponding author. E-mail: ngrijalb@nebrija.es

This is an Open Access article distributed under the terms of the Creative Commons Attribution License (http://creativecommons. org/licenses/by/4.0/), which permits unrestricted use, distribution, and reproduction in any medium, provided the original author and source are credited. 
above all, stops at the figure of the filmmaker Almodóvar. It presents, as main hypothesis, that the filmmaker has contributed with his work to the international knowledge of Spanish culture, empowering its differential values and portraying the social evolution of the country from the 1980s to the present.

If we go through the history of cinema, the best example of how film stories forge national consciences is the triumph of American thought in Western productions. The ideals of the United States of America do not only rest on the discourses of their founding fathers, but also on a legacy of cinematographic works that have managed to feed this patriotism.

The truth is that all countries understood from the beginning the convening power of the new invention. The consolidation of national cinematographies essentially took place during the inter-war period, where film played a decisive role in the moral and spiritual reconstruction of nations.

Cinema turned into a spectacle for the masses and films were erected - assuming Sorlin's definition (1985, p. 28) - as the great discourses of the time. However, although the American case is paradigmatic, it is important to briefly mention other alliances that occurred between cinema and nation.

To solve the problems of identity, France regained its national values by betting on a revisionist and instrumental cinema. For its part, the Soviet cinema of the newly created Soviet Union, "wanted to reflect the unusual and unknown land of the soviets, their ideals and objectives" (Eisenstein, 1969, p. 117).

Sergei Eisenstein, Vsevolod Pudovkin and Dziga Vertov, among others, combined a risky narrative experimentation with discourses of agitation and propaganda. It is not surprising, therefore, that Vladimir Lenin considered film as the most important of the new arts: the dissemination of Marxist ideals was immediate.

At the same time, as Kracauer $(2004$, p. 11) has documented, German cinema renewed its themes and modes of presentation.

\section{Research justification and methods}

That since the premiere of Dark Habits (Spanish: Entre tinieblas, director Almodóvar, 1983), the fame of Almodóvar became international and his films began to be exhibited in the foreign market. A year later, with the premiere of What Have I Done to Deserve This? (Spanish: ¿Qué he hecho yo para merecer esto?, director Almodóvar, 1984) this trend set in and the projection of his films started to enjoy international praise. So much so that, in 1988 he received his first Academy Award nomination, which was an international showcase not only for Women on the Verge of a Nervous Breakdown (Spanish: Mujeres al borde de un ataque de nervios, director Almodóvar, 1988), but also for his cinematography and, even, for the author himself. Moreover, the film won a British Academy Film Award and a David di Donatello. While this is already commendable, we must review the case of All about My Mother (Spanish: Todo sobre mi madre, director Almodóvar), since it is the most internationally awarded Spanish film: Academy Award for best foreign film, a British Academy Film Award and a César Award, as well as the Best Director Award for Almodóvar at the Cannes Film Festival. 
With this global positioning, Almodóvar became the most internationally successful Spanish director and, precisely, this study will attempt to determine whether your creative process, in addition to promote his work, serves as a platform for the dissemination of the Spanish identity, which is also known as Brand Spain.

Based on this general objective, we have set the following specific objectives:

- Study the identity-shaping capacity of cinema in relation to a nation, paying special attention to Spain.

- Identify stereotypes associated to the image of Spain.

- Analyze Almodóvar's work according to those identification elements.

- Determine whether Almodóvarian cinema works as a showcase of the Spanish stereotypes and whether his filmography represents the social evolution of the country.

To achieve these objectives, the research design combines two methods. On the one hand, documentary research for descriptive purposes, based on the review of the most significant references about cinema as a channel of national identity and about Almodóvar and his relationship with Spanish culture. On the other hand, quantitative research focused on the analysis of Almodóvar's filmography according to a pattern that collects characteristic items of the culture and brand image of Spain.

This analytical model includes variables that have been designated on the basis of a previous exploratory research work that compared studies on the Spanish identity. We reviewed scientific studies related to the perception of this culture based mostly on the Barometer of the Elcano Royal Institute $(E R I)^{1}$ (2017). The analysis of the image of Spain abroad is based on a structured questionnaire applied to a sample of people from 11 different countries and aged 18 to 70 years $^{2}$.

The study identifies a series of stereotypes that shape the image of Spain abroad. Notable for our research is the fact that Almodóvar himself is mentioned by respondents as a representative of the national identity.

So, Almodóvar is the Spanish director with the most recognition and international diffusion at present, as we have explained at the beginning of this section, and that the barometers themselves on the external image of Spain place him as ambassador of national culture, justify that his work is selected for this research.

The Barometer of the ERI identifies keywords in different contents. We have extracted the common elements related to Spanish culture and the personality of its citizens, around the following central themes:

- Characters. Passion and family.

- Locations. Madrid and other representative locations.

- Sociocultural imaginary. Flamenco, folklore, bullfighting, gastronomy.

These indicators will help us determine whether Almodóvar's filmography is an ambassador of Spanish society and culture and, whether, after analyzing his work according to the previous categories, its representation of society and constumbrist narrative enhance the understanding of the characters' context, motivations and beliefs.

In this regard, it should be noted that renowned authors such as Loew and Luna (2005) indicate that the work of Almodóvar can serve as "excellent vehicle" to narrate changes in Spanish society. Kinder and Almodóvar (1987) has already pointed out that he was managing to change the image of Spain abroad, creating a new cultural model based on modernity. 
The following three symbols were designed to visually summarize the nature of each indicator (Figure 1).

Empirical research has been complemented with the content analysis of Almodóvar's filmography to be able to appreciate with greater depth the indicators and their motivation and, at the same time, underline other characteristic elements of the work of this filmmaker. The sample of analysis is composed of the 20 first feature films Almodóvar has directed so far, without Pain and Glory (Spanish: Dolor y gloria, 2019), and is divided into different stages following the classification proposed by Marta Saavedra Llamas (2013) in relation to the construction of the author's brand image (Table 1).

Applying quantitative and qualitative techniques to the analysis of the filmography allows us to measure certain variables systematically and objectively and make estimations and inferences that favor the understanding of the context.

\section{National construction in Spanish cinema}

The national issue, as it could not be otherwise, was also a direct concern for the Spanish film industry. Therefore, to get to understand the direct relationship between the cinema of Almodóvar and Spain's contemporary identity, it is necessary to point out, concisely, some other milestones.

As García Carrión (2013, p. 116) puts it, in Spain cinema became one of the most popular shows in fairs and sideshows. Against foreign productions, Spanish cinema revealed itself as a phenomenon capable of representing the popular interests of the nation, paying attention to passionate stories and folk tales.

While the dictatorship of Miguel Primo de Rivera favored the production of feature films based on a modern and urban identity - despite the application of a reactionary policy and an evident economic overprotection - the complex 1930s underpinned a timid collective and democratic memory that was interrupted, tragically, by the Spanish Civil War (SCW).

During the Second Spanish Republic, the film industry increased the use of the most identitary symbols in national productions to face the success of international cinema.

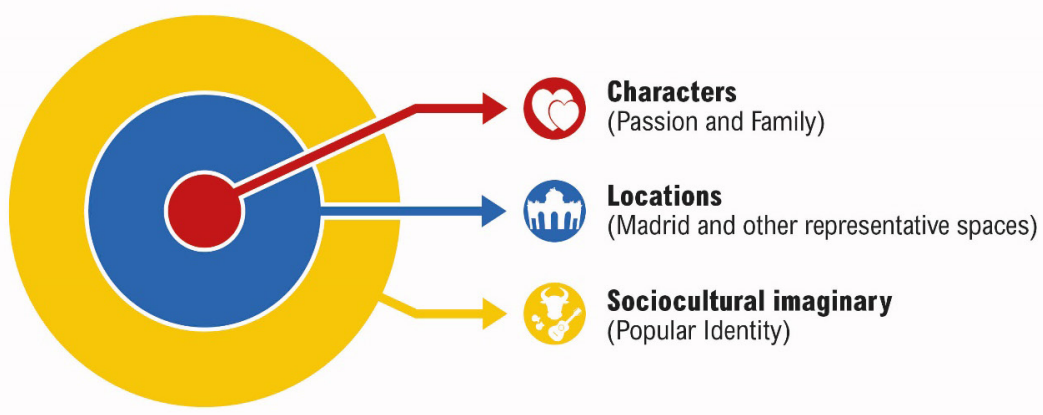

Figure 1. Research indicators (source: created by authors) 
Table 1. Creative stages of Pedro Almodóvar (source: created by authors)

\begin{tabular}{|c|c|c|c|}
\hline First stage & Second stage & Third stage & Fourth stage \\
\hline $\begin{array}{l}\text { Presentation of the } \\
\text { product }\end{array}$ & $\begin{array}{l}\text { Consolidation of the } \\
\text { product }\end{array}$ & $\begin{array}{l}\text { Reflection on the } \\
\text { product }\end{array}$ & $\begin{array}{l}\text { Global knowledge of } \\
\text { the product: The Al- } \\
\text { modóvarian universe is } \\
\text { already internalized }\end{array}$ \\
\hline $1980-1983$ & 1984-1990 & 1991-1999 & $2000-2018$ \\
\hline $\begin{array}{l}\text { 1) Pepi, Luci, Bom y } \\
\text { otras chicas del montón } \\
\text { / Pepi, Luci, Bom and } \\
\text { Other Average Girls } \\
\text { 2) Laberinto de pasiones } \\
\text { / Labyrinth of Passion } \\
\text { 3) Entre tinieblas / Dark } \\
\text { Habits }\end{array}$ & $\begin{array}{l}\text { 4) ¿Qué he hecho yo } \\
\text { para merecer esto? / } \\
\text { What Have I Done to } \\
\text { Deserve This? } \\
\text { 5) Matador / Matador } \\
\text { 6) La ley del deseo / Law } \\
\text { of Desire } \\
\text { 7) Mujeres al borde de } \\
\text { un ataque de nervios / } \\
\text { Women on the Verge of } \\
\text { a Nervous Breakdown } \\
\text { 8) ¡Átame! / Tie Me Up! } \\
\text { Tie Me Down! }\end{array}$ & $\begin{array}{l}\text { 9) Tacones lejanos / } \\
\text { High Heels } \\
\text { 10) Kika / Kika } \\
\text { 11) La flor de mi } \\
\text { secreto / The Flower of } \\
\text { My Secret } \\
\text { 12) Carne Trémula / } \\
\text { Live Flesh } \\
\text { 13) Todo sobre mi } \\
\text { madre / All about My } \\
\text { Mother }\end{array}$ & $\begin{array}{l}\text { 14) Hable con ella / } \\
\text { Talk to Her } \\
\text { 15) La mala educación } \\
\text { / Bad Education } \\
\text { 16) Volver / Volver } \\
\text { 17) Los abrazos rotos / } \\
\text { Broken Embraces } \\
\text { 18) La piel que habito / } \\
\text { The Skin I Live In } \\
\text { 19) Los amantes } \\
\text { pasajeros / I'm So } \\
\text { Excited! } \\
\text { 20) Julieta / Julieta }\end{array}$ \\
\hline
\end{tabular}

Note: The original titles in Spanish are followed by the titles with which the films were released in the English-speaking countries.

Benito Perojo embodied the figure of the self-sufficient, prolific director, who knew how to connect from the outset with the preferences of the average viewer (Díez, 1999, p. 34).

However, some obstinate critics of the time branded Perojo's films as too international. In this way, according to Cabeza San Deogracias (2005, p. 17), the brightest production companies began to cultivate a more racial genre that exposed, from beginning to end, the good Spanish ideals. This gave way to the emergence of the españolada: a variant of constumbrist comedy that employed the traits of Spanish identity excessively.

Curiously, far from disappearing, the españolada remains alive in cinema, as well as in numerous television series, which repeatedly bet on a Spanish imaginary full of clichés. Today, a large number of commercial films, with Spanish Affair (Spanish: Ocho apellidos vascos, director Emilio Martínez-Lázaro, 2014) on top, base their success on the permanent questioning of cultural symbols and the constant dialectic between North and South.

Getting back to the historical account, at the beginning of the SCW, national identity cracked immediately in Spain. Both sides used cinema as a propaganda weapon.

It is easy to understand how the SCW affected the young film industry. From 1939, the popular memory would rest on the guidelines of a single side, the national one: the Francisco Franco's regime understood from the outset the need to forge a patriotic film industry in line with its pompous identity.

Under an authoritarian and centralist policy, film producers presented stories that extolled the ideals of unity and tradition. However, analyzing forty years of the Franco's regime as an immutable period would be a misreading. 
This ideological state intervention (Caparrós Lera, 1983, p. 29) consolidated in the 1940s a national spirit that led to the production of films that celebrated, at all times, the heroic deeds of the winners.

Once the military theme became exhausted, the industry embarked on the rescue of the soul and morals: a historical and religious cinema filled the screens with decent and courageous protagonists.

As Deltell Escolar (2005) has pointed out, the 1950s gave way to a constumbrist, substantially old-fashioned, cinema. Spanish productions converged with the españolada and diverse folk artists, and the inflated nationalist discourses gave way to moral problems.

In this context, it is easy to understand the impact of Furrows (Spanish: Surcos, director José Antonio Nieves Conde, 1951) on Spanish cultural life. The work of Nieves Conde contained a powerful plot of social protest.

While the defenders of the Franco tried to safeguard the old patriotic ideals, filmmakers such as Luis García Berlanga and Juan Antonio Bardem questioned the official image of a country filled with castanets and tambourines. Welcome Mr. Marshall! (Spanish: ¡Bienvenido, Mister Marshall!, director García Berlanga, 1953) exemplifies the clever and acid treatment that these new filmmakers gave to film.

However, it was not until the arrival of developmentalism, in the 1960s, when the Franco's Government started to apply more liberalizing policies that promoted social and economic changes. Technocrat governments were somewhat more lenient regarding the construction of discourses, and cinema, as a reflection of social trends, adjusted to the so called Third Way.

The film catalogue of late Francoism, fruit of survival, delved into the most controversial social issues, escaping, for sure, from the most direct censorship.

The arrival of democracy marked the start of a new period for the historical memory.

All of these changes, fortunately, allowed the representation of realities that had been virtually banned in Franco's cinema. National identity, in this sense, was problematized because perspectives multiplied and the audiovisual media fostered the image of a new country. Almodóvarian cinema - as a paradigm of the self-sufficient and prejudice-free cinema - does not imply in principle a direct confrontation with Spanish popular iconography but rather a re-reading of the codes from a postmodern ideological basis.

\section{The figure of Pedro Almodóvar}

Born in a village from La Mancha, Spain, in a humble family ruled by a matriarchal system, Almodóvar was the result of the sum of a national-catholic school and a rural ecosystem. In order to thrive in developmentalist Spain, at the end of the 1960s Almodóvar Caballero's family traveled to Madrid, Spain where movies were released first (Strauss, 2001, p. 179). It was precisely this clash between folk tradition and the first attempts of modernity what conditioned his aesthetic and thematic universe.

During the day, Almodóvar worked at Telefónica, but the already effervescent nightlife of Madrid in the 1970s brought him closer to other artists with similar concerns. Actors, actresses, singers and painters and characters of an incipient underground culture, led the so called The Madrid Scene (Spanish: La Movida Madrileña), in which Almodóvar played a key role. 
After his early work in super 8 film, where he already seemed to share many characteristics of the camp aesthetic (Yarza, 1999, p. 165), Almodóvar started to finance, with the help of his friends, his first full-length film: Pepi, Luci, Bom and Other Average Girls (Spanish: Pepi, Luci, Bom y otras chicas del montón, 1980).

To address all of his projects in a more independent manner, and already considered as a film director with his own cinematic universe, Almodóvar, along with his brother Agustín Almodóvar, funded El Deseo production company in 1986. Since then, the international impact of the Manchegan filmmaker multiplied. The definitive consolidation occurred ten years later, in 1999, when he won an Academy Award for best foreign-language film for All about My Mother and then, in 2002, when he won the Academy Award for best original screenplay for Talk to Her (Spanish: Hable con ella, director Pedro Almodóvar).

\section{The image of Spain in the cinema of Pedro Almodóvar}

\subsection{The passionate nature of the characters and the weight of the family in the story}

Pedro Almodóvar's films revolve around strong and visceral characters. This is because, although his stories may seem far removed from the viewer's everyday life, they rely on universal feelings that generate familiarity, empathy and identification. In all of his stories the key theme is love: relationships between characters who live their life to the fullest and experience heartbreaking situations.

Pedro Almodóvar indulges his characters and depicts them with a humanist approach devoid of personal or social judgements.

The director's storytelling style reflects a recurrent approach: one central plot with subplots that adorn, emphasize and even lighten up the key story. Thus, we can find different topics in the same film, which generates in turn a creative tendency to develop multiple plots.

Very frequently this character is a woman. In fact, this is the case in $70 \%$ of the films (excluding Law of Desire (Spanish: La ley del deseo, director Pedro Almodóvar, 1987), led by the character of Pablo Quintero; Live Flesh (Spanish: Carne Trémula, director Pedro Almodóvar, 1997) with Víctor Plaza; Talk to Her, centred on Benigno Martín and Marco Zuluaga; Bad Education (Spanish: La mala educación, director Pedro Almodóvar, 2004) focused on Juan; The Skin I Live In (Spanish: La piel que habito, director Pedro Almodóvar, 2011) because the character of Vera Cruz is actually Vicente Guillén Piñeiro, whose sex is surgically reassigned without consent, by Dr. Robert Ledgard; and I'm So Excited! (Spanish: Los amantes pasajeros, director Pedro Almodóvar, 2013) an ensemble film). These women have a strong personality, they are warriors and fighters; they are generally optimist but, sometimes, are also insecure; they come with great emotional baggage and deficiencies of all kinds.

Pedro Almodóvar (Pathé, 2006) has defined his leading woman in the following way: "Capacity to survive, fighter, a Mediterranean woman, who is exuberant and very spontaneous and is not afraid of being ridiculed".

Virtually all the main characters of the Almodóvarian universe, both men and women, are related to the filmmaker himself, since his cinematography is full of autobiographical references: La Mancha, The Madrid Scene, sexual liberation, the world of cinema and even 
his artistic preferences, since his characters are surrounded by the music, literature, painting, sculpture and cinema that are closest to him.

Equally autobiographical is the fact that his characters maintain an emotional tie with their family because Pedro Almodóvar turned its relationship with his mother into a symbol of pride and included Francisca Caballero in different films.

Pedro Almodóvar's filmography is so riddled with references about family relationships and the relationship of characters with their environment is always important in the construction of the story itself, either through positive ties or negative contrasts. Family relationships are positive in most of Pedro Almodóvar's films, in 12 or $60 \%$ to be precise (films number 3, 6, 8, 9, 10,11, 12, 13, 14, 15, 16, 17) (Table 1).

In Dark Habits, the family relationship develops inside a convent. The nuns form a strong family that is loyal to the Mother Superior, although sometimes they disagree with her. In Law of Desire, the family relationship is established between Pablo Quintero and his transsexual sister Tina Quintero, who come from a family that has been broken precisely by the law of desire. In their reunion, they manage to become a close-knit family and the main support for each other.

With Tie Me Up! Tie Me Down! (Spanish: ¡Átame!, director Pedro Almodóvar, 1989) we discover a new relationship between two sisters, Marina Osorio and Lola Osorio. It is a clear, solid and seamless bond; in fact, when Lola Osorio processes the shock of the kidnapping, she encourages Marina Osorio to stay with Ricky, whom she symbolically accepts with a musical number, which suggests a possible happy ending for the new love story.

In High Heels (Spanish: Tacones lejanos, director Pedro Almodóvar, 1991), the main relationship between mother and daughter initially seems distorted and full of shortcomings. Becky del Páramo is an artist who has always placed his career and relationships before her family; Rebeca, on the other hand, admires her mother and does several things for her mother's benefit.

In Kika (Spanish: Kika, director Pedro Almodóvar, 1993), the character of Ramón is so tormented by the loss of his mother that he creates a sort of altar for her. In Pedro Almodóvar's cinema it is common to use the family as the true core of faith and this decorativesentimental use of religion is very symbolic in this case.

The Flower of My Secret (Spanish: La flor de mi secreto, director Pedro Almodóvar, 1995) highlights decisively the importance of the family and its protection capacity, as well as the need to explore and feel its origins. Leo Macías has just been despised by her husband with whom she had a troubled and distant relationship; this leads her to take a bottle of pills that leave her on the brink of death. The voice of her mother in the answering machine is what brings her back to life and to reality.

In Live Flesh, the importance of family is reflected at the start of the film, through the birth of Víctor Plaza and the way her mother is supported by her sister, who helps her deliver the baby by cutting the umbilical cord with her own teeth.

For its part, All about My Mother shows more than ever the love of a mother for her child and her strength to cope with adverse circumstances, always keeping her child at the forefront of her mind. For Manuela, Esteban is everything, so she has to learn to live again after his death. Moreover, the film is loaded with family-related references that also reinforce the 
intertextual nature of Pedro Almodóvar's works. Thus, we find the work of Tennessee Williams, A Streetcar Named Desire (2004); Manuela encounter with Barcelona, Spain through the city's most iconic symbol: Antoni Gaudís Sagrada Família; the appearance of Marc Chagall's Madonna of Village (1942), which is falsified by Rosa's mother, and shows the Mary, mother of Jesus as a protecting being, carrying her son in her arms. Another reference is Manuela's mentioning of the arrest of Jorge Rafael Videla, which directly connects the story with the drama of the mothers of the Plaza de Mayo of Argentina.

At the end of the film, Huma Rojo rehearses the text of her last play, inspired by a piece written by Federico García Lorca that highlights the love between mother and son and the devastation that the death of the latter left on the former.

Talk to Her shows the relationship with the family through two sick women, Alicia Roncero and Lydia González. While Lydia González has the support of her sister and her partner, who suffer seeing her comatose after being gored in the bullring, Alicia Roncero has the financial support of her father and the love of her female dance teacher, who plays an almost maternal role.

The role of the mother is also key in Bad Education since although the relationship between the brothers is totally destructive because of Juan's ambition, Ignacio is still tied to his family by a bond of love and grieve. In addition, as is the case in Dark Habits, life in the religious center gives way to the formation of a family, not between clerics and children, which results totally malicious, but between the students themselves.

In film number 16, the intensity of the family relationship is clear and is at the center of the plot. In fact, its pressbook describes Volver (Spanish: Volver, director Pedro Almodóvar, 2006) as "a family of women". Irene Trujillo, Raimunda, Soledad, Aunt Paula, Paula and Agustina form a family that will show its strength and affection, the magical encounter, and their forgiveness and forte to face events despite the consequences for the sole purpose of protecting the family.

Finally, in Broken Embraces (Spanish: Los abrazos rotos, director Pedro Almodóvar, 2009) the emotional intensity is evident; the amour fou, inherent to surreal stories, determines the relationship between Mateo Blanco, a blind film director, and the love of his life, Magdalena "Lena" Rivas. It is not coincidence that part of this melodrama is set in Lanzarote, Spain, known as the Island of Volcanoes, a symbolic space that enhances the passionate nature of the plot.

At the same time, the theme of the family emerges clearly throughout the whole film. To survive tragedy, Mateo Blanco, who now calls himself Harry Caine, forms his own family with the beings that surround him; guide dogs that meet his needs and heal, or at least try to heal, all his wounds.

The importance of the family is also highlighted in the rest of the films (40\%), but with negative overtones (films 1, 2, 4, 5, 7, 18, 19, 20) (Table 1).

The first film shows that Pepi only has a money-based bond with her parents; Luci is abused by her husband and Bom lives away from her family.

Labyrinth of Passion (Spanish: Laberinto de pasiones, director Pedro Almodóvar, 1982) shows an unusual and distant family relationship. It is explored in two stories: on the one hand, the relationship between Sexilia and her father and, on the other hand, the relationship between the members of the laundromat. 
What Have I Done to Deserve This? shows a completely dysfunctional family. Gloria is in a broken marriage that has lost all respect; the relationship with her mother-in-law is distant, cold and characterized by a lack of mutual understanding. The relationship with her children is totally surreal because she does nothing to prevent her underage sons from sleeping with older men and peddling heroin. Gloria is a victim of exhaustion and emotional weariness.

In Matador (Spanish: Matador, director Pedro Almodóvar, 1986) the relationship between mother and son is grim and is the best example of destruction in the character played by Antonio Banderas; he incriminates himself in several criminal offences only to escape his family life: oppressive, insensitive, distant and based on guilt and reproaches.

Women on the Verge of a Nervous Breakdown is based not only around the destruction of the relationship of Pepa Marcos and Iván, but also on the complicated family structure formed by the latter.

The Skin I Live In is a work of interior spaces, shadows and questions, and unlike most of Pedro Almodóvar's filmography, it shows passion as agonizing and paralyzing. It is (also) a work of absences: Dr. Robert Ledgard has lost his wife and daughter, but his lack of scruples does not prevent him from finding a victim to recover his creative power, after numerous experiments. The prisoner is Vera Cruz, a seemingly young female who, before falling in the hands of the intriguing doctor, was a young man named Vicente Guillén Piñeiro, who was sick of his monotonous life in a village in Galicia, Spain).

Precisely, the greatest atomization of the family unit is found in I'm So Excited!, an ensemble absurd comedy film whose narrative is set al.ost completely on an airplane. Although the director defines different characters' profiles, the passengers behave, ultimately, as stereotypes.

Julieta (Spanish: Julieta, director Pedro Almodóvar, 2016) is the last work analyzed in this academic study. It is a refined drama, despite the temporary jumps it presents, where the passionate nature of the characters determines the story and family relationships drive the plot. Julieta Arcos is desperately searching for her daughter Antía; the purifying letters this mother writes reflect the pain and loneliness that she has cultivated over the years. Loneliness is the motive of this film. Julieta, precisely explores the lack of affection and looks into silences. It deals with maternity from the perspective of pain and estrangement, as it is the disappearance of the character what indirectly causes the separation of these two women.

As we can see, Pedro Almodóvar's full filmography is filled with references to family that reveal its importance in the characters' culture, personality and evolution, whether positive or negative constructions. All of them are intense and do not fit, in some way or another, the traditional family model. The passionate nature of the characters and the weight of family in the story are items that appear in $100 \%$ of Pedro Almodóvar's cinematography. After the content analysis, the following section examines the films in which this thematic axis intensifies and affects more the narrated story (Figure 2).

\subsection{Settings and locations: Madrid, the most representative city}

Pedro Almodóvar's cinema needs to be anchored to a specific and recognizable space to feel unique. As debtor of modern narrative, the Spanish director understands the filmic space as a basic element for the emotional development of his characters. Following a recurrent theme 


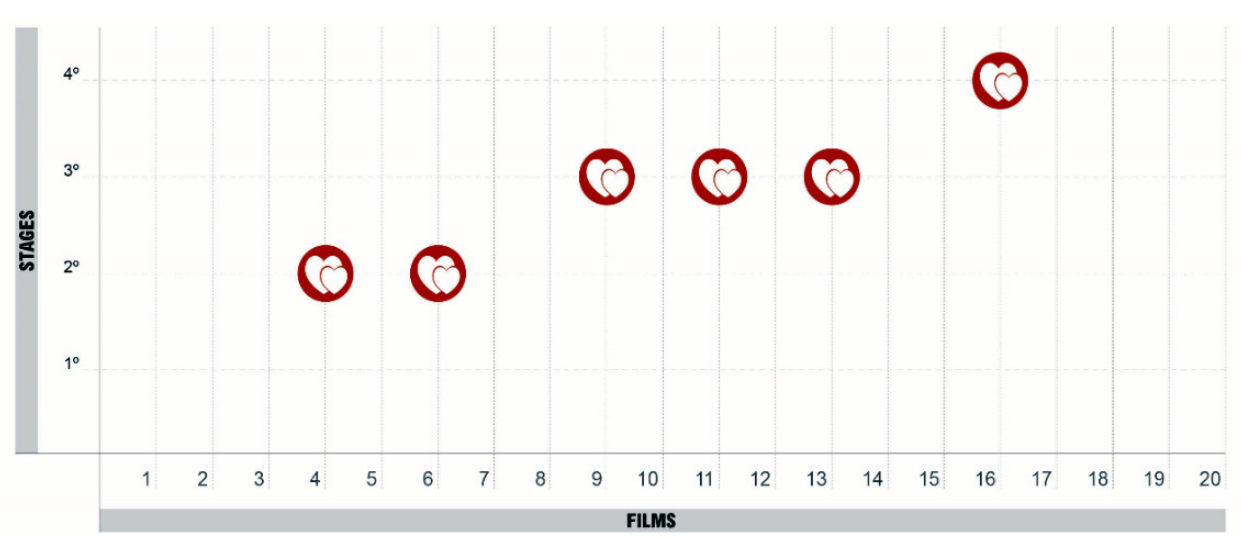

Figure 2. Characters indicator (passion and family): most representative films (source: created by authors)

in Spanish cinema, the filmmaker's works reflect on the contrast between the rural and urban spaces. His sentimental education, linked to rural landscapes, is complemented perfectly with an urban learning. In this sense, Seguin Vergara (2009, p. 30) rightly proposes that to each of the author's films "corresponds a sight, a fragment of a part of the city".

All creative process of the filmmaker is intimately linked to the city of Madrid, although from The Flower of My Secret onwards we find continuous flights to other, mostly rural, destinations.

Pepi, Luci, Bom and Other Average Girls is presented as a costumbrist punk film where the aesthetic obsessions of the director are very blatant and excessive. The characters' profiles are introduced in the streets, but their behaviors are shaped in indoor spaces (modest and eccentric apartments, discotheques and impossible gambling dens).

The street feeling is acute in Labyrinth of Passion, a ludicrous film that, in the words of Grijalba de la Calle (2016, p. 588), reveals how fun the city of Madrid used to be. Pedro Almodóvar, surely, translates his life experience to the big screen; Madrid's market El Rastro, is the epicenter of this hedonistic film.

What at first seems to be a pop pastiche, becomes with the plot development into a psychedelic melodrama. Pedro Almodóvar's Madrid is like a roller coaster as he suggests in the following statement (Strauss, 2001, p. 34): "My desire was to show that Madrid was the first city in the world, a city everybody visited and where everything could happen".

With Dark Habits, the filmmaker seems to want to atone for his sins. Against the vigilance of the city, Pedro Almodóvar focuses his plot in a convent where prayers comer after boleros. With the choice of this space, which is mostly feminine, the director gives prominence to intimate dynamics.

In 1984, the Manchegan filmmaker explores avenues with a stylized realism in What Have I Done to Deserve This?. This film marks the reunion of the director and another Madrid that is completely distanced from the pageantry of the scene: life in a modest suburban neighborhood, life in a working-class and quiet neighborhood, where many families live in 40-square-meter apartments. 
In Matador, describes as a thriller, the city lives in permanent tension. A diversity of crazy characters, and bullfighting scenes, summon Eros and Thanatos in the vicinity of El Madrid de los Austrias (the old center of Madrid).

This stage of creative consolidation continues with Law of Desire. In this production, Pedro Almodóvar gives the city a sensual and seductive capacity.

Women on the Verge of a Nervous Breakdown is not only a great comedy, but also a love song for the city of Madrid. Or rather, the idea that we all have of Madrid. In this film, the city is a device that works seamlessly. The famous attic where Pepa Marcos lives, with Madrid's skyline in the background, is one of the most celebrated urban images of the filmmaker; and, however, this colorful terrace, the setting for one thousand and one adventures, is a celebrated set.

In Tie Me Up! Tie Me Down!, Pedro Almodóvar's eighth feature, the urban experience is linked to Ricky, the male protagonist of the film, an unstable young man hooked on his depraved desires.

With High Heels, Pedro Almodóvar inaugurates a new narrative look, in which he opens up through melodrama, and the urban space, which continues to have great importance in the development of the plots, no longer manages to heal the wounds of the protagonists. Virtually the whole filmography Pedro Almodóvar directed in the 1990s must be read as a (loving) score settling with the fast-paced urban life.

In 1997, Pedro Almodóvar makes a turn in his career with Live Flesh. This is not only because it is a free adaptation of a novel, but also because its plot not only develops in the present. In this film, the director jogs his memory and, from that moment onwards, it is difficult to find a nice depiction of the city in his cinematography. In this way, and as something expected and duly announced, Pedro Almodóvar gives prominence to the city of Barcelona in All about My Mother.

From this moment, the natural evolution of his films takes Pedro Almodóvar through complex narrative paths.

In Bad Education, Madrid is only an echo from the past; while in All about My Mother the city is unable to recover already lost desires. Something riskier happens in I'm So Excited!, as Pedro Almodóvar sets most of the film in a transoceanic flight. However, the urban space is important for Pedro Almodóvar to such an extent that Volver, for a moment, marks his return to the inhabited places.

Finally, Julieta, is a story of silences and fragmented spaces. In this film, the locations multiply throughout the Iberian Peninsula, but the desire of the leading female character and possibly also of the director - is to be reunited once again, with maturity and experience, with a city called Madrid.

In short, the presence of Madrid in Pedro Almodóvar's filmography is constant and on multiple occasions the city is another protagonist rather that conditions the feelings of the characters. In fact, the presence of Madrid is permanent and decisive in most of his features. To be precise, in 11 or $55 \%$ of them: $1,2,3,4,5,6,7,8,9,10,12$ (Figure 3).

However, Madrid coexists with other geographical locations, especially with markedly rural spaces, in the rest (45\%) of his films, all of which virtually belonged to the last creative stage: 11, 13, 14, 15, 16, 17, 18, 19, 20 (Figure 3). 


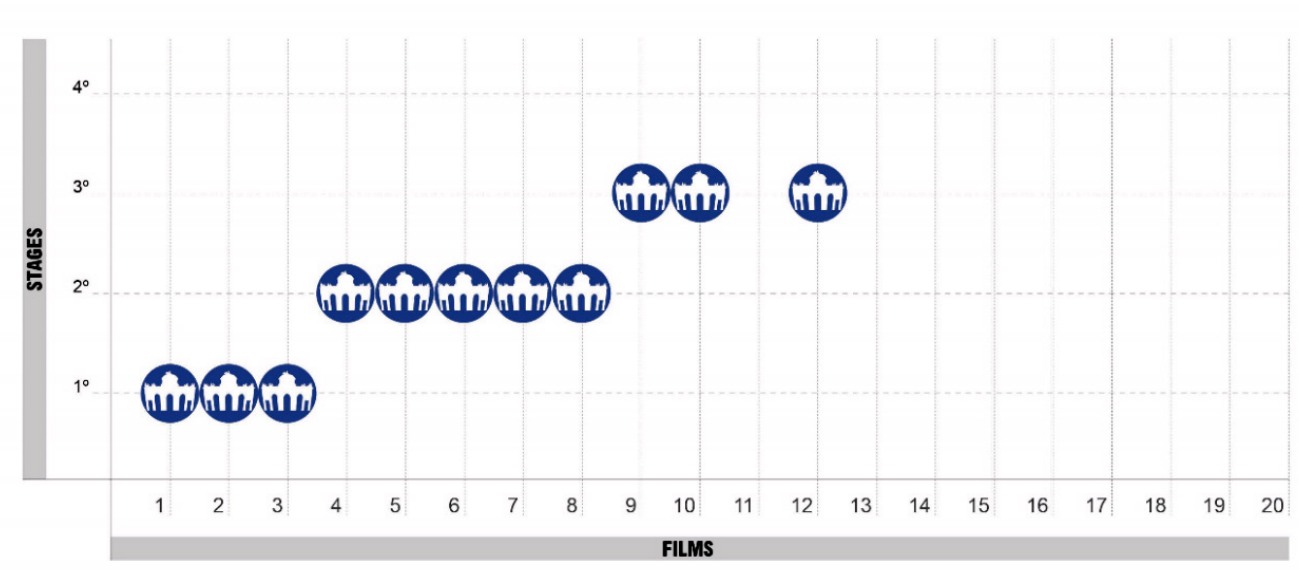

Figure 3. Locations indicator-Madrid: most representative films (source: created by authors)

\subsection{Popular sociocultural imaginary: flamenco, folklore, bulls and gastronomy}

The filmmaker portrays in his work recognizable areas of Spanish culture and geography, with Madrid as the star, as we have seen in the previous section.

His characters are recognizable, normal people, and their way of speaking fits their circumstances and their identity. The cheeky punk girl with marked Madrid accent represented by Bom in the first film has nothing to do with Raimunda from Volver, who has a typical accent from La Mancha and speaks popular slang. Each character plays a real representative role.

This identity can be discovered in the main characters, which are always passionate. The work Pedro Almodóvar is filled up with colorful secondary characters. These creations can generate greater identification with the story in indigenous viewers and constitute a new platform to showcase Spanish popular culture at the international level.

Pepi, Luci, Bom and Other Average Girls explores the housewife and the corrupt policeman (a figure that reappears in Live Flesh as well as in the councilor lady in All about My Mother). Also outstanding is the sequence of the aggression that occurs in the streets to the rhythm of Pablo Sorozábal's Spanish opera The Girl with the Bouquet of Roses (Spanish: La del manojo de rosas, 1934). The original mise-en-scène is complemented with the use of Madrid's regional costume. Alaska y los Pegamoides (funded in 1979) move away from the punk aesthetic to represent the chulapos, i.e., people from certain Madrid neighborhoods, known for their traditional dress.

In Labyrinth of Passion, Sexilia's nosy, intrusive and chatty assistant, and Queti, young woman who runs a laundromat in the neighborhood along with his father.

For its part, Dark Habits presents a diversity of typical characters: nuns, priests, folk singers, market vendors, etc. Just like What Have I Done to Deserve This?, which is a real ode to the middle class and the rural populations. 
With Matador, Pedro Almodóvar takes to the screen one of the most traditional Spanish spectacles, bullfighting, which is then exploited in Talk to Her. In Law of Desire, the character of Ada wants to receive her first holy communion, just so she can dress like a princess: the scene is very typical in Spanish springs, just like the crosses that are made out of flowers and that are stored by Tina Quintero in her house until the summer. In this film religious iconography is also present; a mestizo and popular iconography because, as Sánchez Noriega says,

"the poster-sized photographs of Hollywood actresses and the portraits of virgins fulfil the same religious, although not necessarily Christian, function of protecting the characters or becoming an object of worship" (2017, p. 3).

Women on the Verge of a Nervous Breakdown rescues the figures of taxi drivers and the doorwoman (also Talk to Her, I'm So Excited! and, with less sweet tones, the housekeeper of The Skin I Live In). In addition, the Andalusian friend of Pepa Marcos enriches the story with her accents and panache, while gazpacho becomes another character after the female protagonist prepares it in front of the camera as a recipe tutorial.

In Tie Me Up! Tie Me Down! we learn how to cook pisto, the Manchegan version of ratatouille (in Pepi, Luci, Bom and Other Average Girls it is cod with pil pil sauce, in Volver it is egg flan, among other typical dishes of the Spanish cuisine, in Julieta it is tortilla and we see how its - simple - preparation can calm down the soul for a moment). Moreover, Tie Me Up! Tie Me Down! includes the Holy Week processions, which are startling for the international tourist seeking in Spain saetas, capes, flowers, candles, Nazarenes and penitents.

La Agrado is key in All about My Mother, not only in the plot but also to bring to the screen this typical incorporation of popular characters. Her foul mouth, her impersonation outfits, her devotion to the religious figures she treasures as the most precious family gift, her self-confidence and the way she introduces herself and her life to friends and strangers.

Several typical Spanish spaces with their corresponding characters are portrayed in Bad Education. The religious boarding school children who follow the orders of their teachers, who take unauthorized licenses; the masses and the activities of the choir.

For its part, the tension of Broken Embraces is released with the short "pop exercise" titled Girls and Suitcases, which is a film within the film. Taking advantage of the fact that the protagonists in this drama are a director and an actress, Pedro Almodóvar makes a nod to comedy, while allowing the viewer to connect with women who are more typical of a popular vaudeville.

The truth is that during this last cinematographic stage, Pedro Almodóvar, without being unfaithful to Spanish culture, changes his gaze and storytelling to other latitudes, expanding his references. In Skin I Live In, which is a complex story that communicates directly with European film classics and science fiction movies.

Stereotypes are what condition I'm So Excited!. The limited narrative space does not prevent the social imaginary and popular culture from permeating part of the dialogues in this transoceanic flight.

Finally, in Julieta, the dramatic containment of the proposal does not prevent the deployment of numerous scenes of domestic character, in typically rural environments, jumping from of side of Spain to the another. Facing a spectral Galicia - land of fishermen -, which conditions Julieta Arcos' past, is the female protagonist's family house, located in the Sevillian town of Mairena del Alcor, Spain. 
Outside Madrid, the most identitary representation is that of La Mancha, the birthplace of the filmmaker. Its gastronomy, folklore, popular songs, matriarchies and even landscapes mark The Flower of My Secret and Volver.

Popular traditions are portrayed in the form of satire, revival or homage to the roots of the author; his cinema once again becomes a representative product of Spanish culture abroad.

Also explored in Almodóvarian filmography are the typical summer landscapes with cities filled with terraces and accompanied by a soporific heat.

The fishing tradition and sea culture is present in Julieta. The cordiality between the female neighbors, the recipes that are passed from mothers to daughters, the monasteries from the Franco's era, the Gypsies who sell flowers in the streets and predict good and bad events; the fortune tellers like Bruna in I'm So Excited!, the meetings around a Spanish guitar, the weekly street markets in the plazas, the bobbin lace making, and the deserts dominated by windmills.

All this is accompanied by a musical cocktail that includes pop, bolero, folk, flamenco and traditional songs.

These ingredients have placed the filmmaker under the costumbrismo umbrella. Indeed, if we review the features of this artistic reality, we practically obtain an analysis of the Almodóvarian work, which is also very closely related to the characteristics of the image of Spain abroad, which are in turn items that the barometers still detect.

The peculiarities of the literary movement, linked to the process creative, are the portrait of local spaces where the action develops, the reflection of the popular and the use of vulgar language; the approach to the particular and picturesque without neglecting an overall and very critical view of society.

To close this section, we must confirm that the item is repeated in $100 \%$ of the analyzed cinematography. The analysis indicates that the films that promote Spanish popular culture the most are those listed in the following chart (Figure 4).

\section{Conclusions}

Pedro Almodóvar is Spain's most internationally renowned director and his name is capable of evoking the image of contemporary Spain and the paradigm of the filmmaker commit-

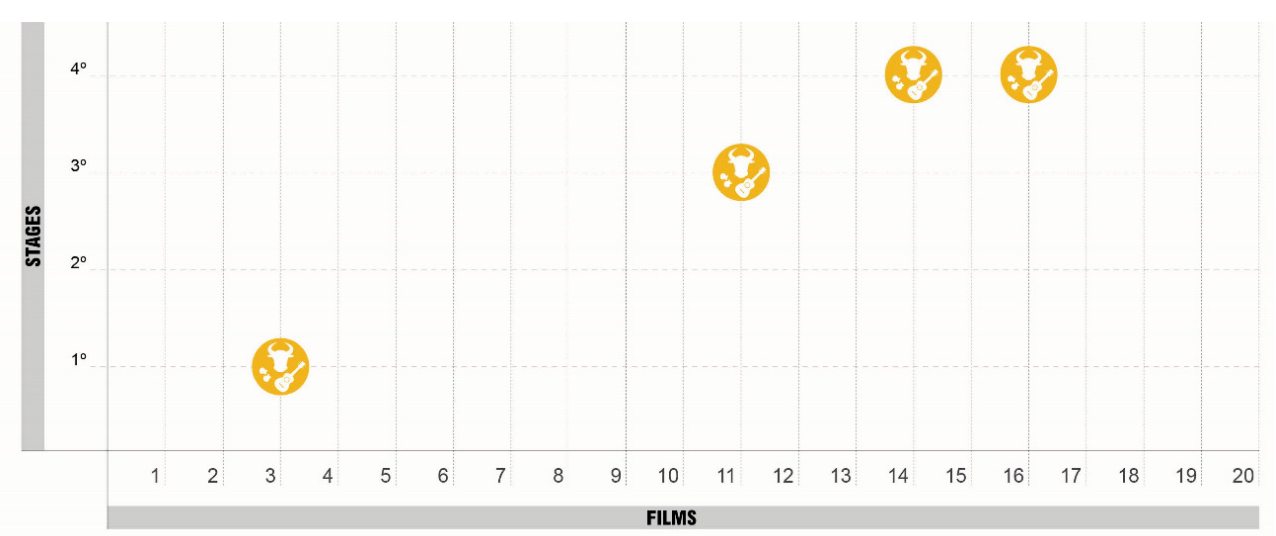

Figure 4. Socio-cultural imaginary indicator (identity): most representative films (source: created by authors) 
ted to his own style. An example of his creative narrative force, and of the influence of his proposals over nearly four decades, is that his surname has become an adjective. Almodóvarian is synonymous with provocation and tenderness, passion and debauchery, tradition and rupture; but also with key Spanish themes depicted through the prism of modernity.

Above all, his first creative stage aimed to twist Spanish passions, traditions and customs.

From 1983, all of Pedro Almodóvar's productions have received popular recognition and have been accompanied by controversy. While half of Spain believes to have found in him the renovator of the popular forms, the other half avoids identifying with his aesthetic universe. Pedro Almodóvar manages to treat clearly and bluntly some social issues that were recently overlooked by Spanish cinema: homosexuality, maternity, women's role in Spanish society, drugs and freedom as personal choice. His cinema witnesses the social evolution.

The exploitation of Spain's national image and brand intensified from 1999 onwards. At this time, he was already a devoted international filmmaker so that the identification platform was global.

In relation to the image foreigners have created of Spaniards, as passionate people with intense family ties, we need to determine whether the cinema of Pedro Almodóvar respects and strengthens this view.

The relationship of the central characters with the family is clear: it is positive in $60 \%$ of cases and negative in $40 \%$. This continues to be a biographical note about the author himself, who recognizes the importance of his family in his work. This tendency to explore his personal experiences obviously brings us closer to his persona, but also to the socio-cultural narrative of an era, to the story of a specific and representative citizen. Pedro Almodóvar does break the traditional family model, by defending different structures and posing the importance of the professional and community environment and, above all, the sense of friendship in Spain.

Madrid is also, in coincidence with the barometer, the iconic location of Pedro Almodóvar's movies. It is a Madrid that evolves, from its first stage, as a space of freedom and growth, to a complex and disturbing city, in the height of artistic maturity.

As his filmography progresses, the author betrays his obsession with the capital and explores other spaces, which are also representative of Spanish culture.

Popular culture is also present in all his creative process, transformed into a costumbrist narrative that portrays, with criticism and even love, a diversity of typical characters, historical or socially turbulent moments, and the most deeply rooted customs and traditions. Pedro Almodóvar's cinematography not only speaks of bullfighting, gastronomy and folklore, but also of Spaniards' relationship with religion, of the aesthetic and profane use of its iconography, and of the color, light, weather, sounds, and flavors of the whole Spain geography, although privileging Madrid and La Mancha. In his 20 features, Pedro Almodóvar manages to offer an overview of almost the whole national map. A clear example is the case of Julieta who travels from Galicia to Seville, crossing the capital, which hurts and soothes the protagonist.

Based on the previous, we can determine that the greater identification of Pedro Almodóvar's films with the Spanish culture, according to the proposed analytical categories, coincides with stages 2 and 3, which in turn coincide, first, with the consolidation of his auteur signature, which is aware of audience's preferences, and then with the reformulation 
and reflection of his aesthetic universe, betting on narrative renewal, which finally takes form in All about My Mother, the most award-winning film of the history of Spanish cinema.

In short, the 20 first films analyzed here draw a map of the social evolution of Spain, either through de narration of various events or by capturing the life development of his characters, always immersed in a specific time or context, of Pain or Glory, as his 21st film, which also respects the three engines of identification with Spanish culture.

\section{References}

Barthes, R. (1986). Lo obvio y lo obtuso: imágenes, gestos, voces. Paidos Ibérica.

Cabeza San Deogracias, J. (2005). El descanso del guerrero: cine en Madrid durante la Guerra Civil española (1936-1939). Ediciones Rialp, S.A.

Caparrós Lera, J. M. (1983). El cine español bajo el régimen de Franco (1936-1975). Publicacions i edicions de la Universidad de Barcelona.

Deltell Escolar, L. (2005). Madrid en el cine de la década de los cincuenta, realismo y espacio cinematográfico. Lecture. Universidad Complutense de Madrid [unpublished source].

Díez, E. (1999). Los acuerdos cinematográficos entre el franquismo y el Tercer Reich (1936-1945). Archivos de la Filmoteca, 33, 34-60.

Eisenstein, S. (1969). Film form: essays in the film theory. J. Leyda (Ed.). A Harvest Book.

García Carrión, M. (2013). Por un cine patrio: Cultura cinematográfica y nacionalismo español (19261936). Publicacions de la Universitat de València.

Grijalba de la Calle, N. (2016). La imagen de Madrid en el cine español (PhD/Doctoral Thesis). Complutense University of Madrid. Madrid. https://eprints.ucm.es/38113/1/T37383.pdf

Loew, C., \& Luna, A. (2005). De la M30 a Hollywood Boulevard: la proyección internacional de la imagen de España en el cine de Almodóvar. In F. A. Zurián \& C. Vázquez Varela, Almodóvar: el cine como pasión (pp. 409-418). Cuenca: Ediciones de la Universidad de Castilla-La Mancha.

Kinder, M., \& Almodóvar, P. (1987). Pleasure and the New Spanish mentality: a conversation with Pedro Almodóvar. Film Quarterly, 41(1), 33-44. https://doi.org/10.2307/1212326

Kracauer, S. (2004). From Caligari to Hitler: a psychological history of the German Film. L. Quaresima (Ed.). Princenton University Press.

Pathé. (2006). Volver vu par Pedro Almodóvar. Feature report directed by Laurent Weil for Pathé in collaboration with Canal+, France.

Real Instituto Elcano: Royal Institute. (2017). Barómetro de la imagen de España: Resultados febreromarzo de 2017, $7^{a}$ oleada. http://www.realinstitutoelcano.org/wps/wcm/connect/c1198845-b5f140b5-b134-cb38d5615373/7BIE_Prensa_mayo2017.pdf?MOD=AJPERES\&CACHEID=c1198845b5f1-40b5-b134-cb38d5615373

Saavedra Llamas, M. (2013). La estrategia de comunicación en el cine de Pedro Almodóvar: influencia de la promoción en el desarrollo y consolidación de la trayectoria del autor (PhD/Doctoral Thesis). Complutense University of Madrid, Madrid. https://eprints.ucm.es/19976/1/T34299.pdf

Sánchez Noriega, J. L. (2017). Universo Almodóvar: estética de la pasión en un cineasta posmoderno. Alianza Editorial. https://doi.org/10.12795/AdMIRA.2017.02.07

Seguin Vergara, J.-C. (2009). Pedro Almodóvar, o la deriva de los cuerpos. Tres Fronteras Ediciones.

Sorlin, P. (1985). Sociología del cine: la apertura para la historia de mañana. Fondo de Cultura Económica.

Strauss, F. (2001). Conversaciones con Pedro Almodóvar. Ediciones AKAL, S.A.

Williams, T. (2004). A Streetcar named Desire. New Directions Publishing Corporation. 
Yarza, A. (1999). Un caníbal en Madrid: la sensibilidad "camp" y el reciclaje de la historia en el cine de Pedro Almodóvar. Ediciones Libertarias/Prodhufi.

\title{
KŪRYBINIS KINEMATOGRAFINIS PROCESAS TIRIANT NACIONALINI TAPATUMĄ: PEDRO ALMODÓVARAS IR ISPANIŠKŲJŲ STEREOTIPŲ PROPAGAVIMAS
}

\author{
Marta SAAVEDRA LLAMAS, Nicolás GRIJALBA DE LA CALLE
}

\begin{abstract}
Santrauka
Kultūrinè raiška ir kūrybiškumas padeda formuoti nacionalinị tapatumą, filmo patirtis atspindi visuomenę. Pagrindinè šio tyrimo ašis - būdas, kurị pasitelkiant Pedro Almodóvaro filmai padeda geriau suprasti Ispanijos kultūrą. Šis tyrimas atliekamas dviem metodais - aprašomąja dokumentika ir filmų kūrèjo darbo analize. Pastaroji apima dvi mažesnes dalis: kokybinę analizę, grindžiamą modeliu, skirtu ịvairiems kintamiesiems nagrinèti, susijusiems su tuo, kaip Ispanija suvokiama užsienyje remiantis stereotipais, ir kiekybinę analizę, išryškinančią tolesnes procedūras, padedančias priartèti prie nacionalinès kultūros klausimų. Šiame tyrime plètojama izžvalga įrodo, kad Almodóvaras plètoja ispaniškąjt tapatumą išties per savojo kūrybinio viseto prizmę ir igalina stereotipus, tačiau suteikia jiems šiuolaikiškumo: jis pabrèžia šeimos vaidmenị, tačiau priešinasi tradiciniam modeliui; žvilgsnị ị Madridą (Ispanija) jis nukreipia ispaniškojo tapatumo tarptautinių standartų kryptimi, ir tai tampa jo kūrybos branduoliu; be to, jis pateikia tam tikrų Ispanijos populiariosios kultūros elementų iš folkloro, gastronomijos, bulių kovų ar kaimo gyvenimo.
\end{abstract}

Reikšminiai žodžiai: costumbrismo, kūrybiškumas, šeima, nacionalinis tapatumas, Madridas, Pedro Almodóvaras, ispanų stereotipai. 